\title{
A Study on the Self-Sustaining Solar Module by Utilizing Solar Cell from Non-Degradable Waste
}

\author{
Farah Aina Mohd Jamal', Juliza Jamaludin ${ }^{*}$, Syarfa Najihah Raisin', Mus'ab Sahrim¹, \\ Irneza Ismail $^{1}$, Sharma Rao Balakrishnan ${ }^{1}$, Wan Zakiah Wan Ismail ${ }^{1}$, Bushra Naeem ${ }^{2}$ \\ Abdullah Solihin Mohd Fauzi', Ahmad Syahmi Mohd Zain', Fatinah Mohd Rahalim', \\ Nur Arina Hazwani Samsun Zaini ${ }^{1}$
}

1 Electronic Engineering Programme, Faculty of Engineering and Built Environment, Universiti Sains Islam Malaysia (USIM), 71800 Negeri Sembilan, Malaysia.

2 Faculty of Information and Communication Technology, Balochistan university of IT, Engineering and Management Sciences (BUITEMS), Takatu campus Quetta, Pakistan.

Email*: juliza@usim.edu.my

Received 28 Oktober $2020 \mid$ Revised 06 Nopember 2020| Accepted 10 Januari 2021

\begin{abstract}
Presently, Malaysia is fostering growth in the green energy sector in order to reduce its carbon emissions and contribute in the fight against global warming. Renewable Energy (RE) such as solar cell could no longer be considered as a green technology because at the end of their lifecycle, they become nonbiodegradable waste which in turn constitutes pollution and contributes to global warming. Thus, the aim of this research is to study a self-sustaining solar module produced by upcycling solar cells from nonbiodegradable waste. Several solar cells from electronic devices were reused in this study. The results obtained show that a combination of $4 \mathrm{~V}, 3 \mathrm{~V}$ and $2 \mathrm{~V}$ reused solar cells produced $10.20 \mathrm{~V}$ and $47.9 \mathrm{~mW}$ of power. This indicates that the proposed upcycled solar module is feasible and has the potential to aid in the promotion of clean and renewable energy use in order to attain the desired sustainable development goals.
\end{abstract}

Keywords: solar module, self-sustaining, solar cell, non-degradable waste 


\section{INTRODUCTION}

Waste is defined as discarded materials which has no value in ordinary day-to-day use [1]. Solid waste are the undesirable, unusable and unwanted materials or substances that originate from human and animal activities. The generation of solid waste is inevitable. According to UNICEF, solid waste can be further classified into biodegradable and non-biodegradable waste. Biodegradable waste could be decomposed completely by biological processes either in the presence or absence of air. On the other hand, non-biodegradable waste could not be decomposed by biological processes [2]. Their disposal is therefore a major concern.

Proper treatment of wastes must be undertaken in order to mitigate adverse environmental effects. Practicing the three R's (Recycle, Reuse, and Reduce) as specified by the integrated solid waste management principle will save energy as well as other valuable natural resources. Recycling is the process of turning waste into a reusable material or product. It involves breaking down the waste materials and subsequently using them to form another product that is often of lesser quality. However, there is another very specific form of recycling, termed upcycling, that turns waste into a material or product that is of a higher quality [3].

Solar energy is an innovative renewable energy source for electricity generation. Solar panels or photovoltaic modules can deliver direct current electricity, although it is dependent on solar radiation. Solar panels are designed for green energy production and its life expectancy is approximately 25 to 30 years before it needs to be decommissioned. Although renewable solar energy systems release zero emissions during its working phase, limited attention has been given thus far to the end-of-life stage of the photovoltaic modules. Statistics show that the cumulatively, the quantity of solar panels waste has reached 250,000 metric tons worldwide by the end of 2016. This figure is expected to increase up to 7 times by 2030 and ultimately reaching 60 to 78 million tonnes of photovoltaic module waste globally by the year 2050 [4].

Presently, most photovoltaic waste has been discarded at landfills. Because certain amounts of heavy metals and toxic substances are present in the solar cells that are disposed of at landfills, photovoltaic waste may lead to environmental pollution especially with regards to land use, water use and habitat survival [5]. The hazardous substances could enter the soil and water, thus bringing many harmful biochemical and physiological effects to human beings and other living species.

Apart from being landfilled, some of the photovoltaic waste also undergo the process of recycling. However, recycling may not be suitable for all types of photovoltaic modules since the materials are mixed and bonded chemically. Hence, it is difficult to separate them. The process of recycling could cause few disadvantages to the materials. The recycling process involves the removal of materials through various methods such as thermal decomposition and the dissolution of nitric acid. Cell defects or the release of harmful emissions such as carbon dioxide may occur due to the inherent risks of the methods being used. Moreover, the products obtained from recycling are low in value, making it hard to recover the cost of the recycling process itself [3].

The aim of this research is to study a self-sustaining solar module produced by upcycling solar cells from non-biodegradable waste. The objectives of this study are to develop a self-sustaining solar module by using non-biodegradable waste and to evaluate the maximum power capacity of the said self-sustaining solar module.

\section{LITERATURE REVIEW}

Haroon Ashfaq et. al. [6] made a comparative analysis of old, recycled and new photovoltaic modules using the MATLAB software. The efficiency of recycled photovoltaic modules was also explored. 
Based on the input parameters of each module simulated in MATLAB and Simulink, the I-V and P-V characteristics were plotted. The performance of old photovoltaic modules were improved upon whereby the recycled modules showed increments in its voltage, current and generated power as illustrated by the bar graph representation in Fig. 1. The output parameters (P-V and I-V characteristics) of the recycled photovoltaic modules were approximately $90 \%$ of the new modules. The authors concluded that the recycled photovoltaic cells met the quality and performance standards of new photovoltaic products. Hence, recycling is more beneficial since it is a safe and cost-effective process for the disposal of old photovoltaic solar panels.

A. Abate [7] investigated the use of perovskite instead of silicon and cadmium telluride in solar cells. The environmental and toxicological implications of lead and its existing regulations were discussed, later arriving at the suggestion of using perovskite that is lead-free in order to deliver a sustainable solar system technology. Based on the aforementioned author's analysis, the perovskite solar cells were found to be able to directly convert solar light energy to electrical power with a very high level of efficiency as compared to cells using current technology. Moreover, tin-based perovskite's oxidative instability could cause it to spontaneously degrade into toxicologically-inactive compounds once it comes into contact with air.

A study by K. Harding et al [8] investigated and made comparisons on the costs involved and efficiency limits achievable by zinc air batteries, hydrogen cells and solar panels as potential power sources for electric vehicles. Both solar panels and zinc air batteries were found to have the best performance for the intended end use. Additionally, most of the environmental damage that results from zinc extraction is in the form of liquid waste which is easier to control and treat than atmospheric emissions. However, due to its corrosive nature, only up to $30 \%$ of the zinc could be recovered by recycling. Silicon, which is part of a solar cell, can be recycled and then reused to produce solar panels. Hence, the abovementioned authors concluded that both zinc air batteries and solar panels could potentially be sources of power for electric vehicles.

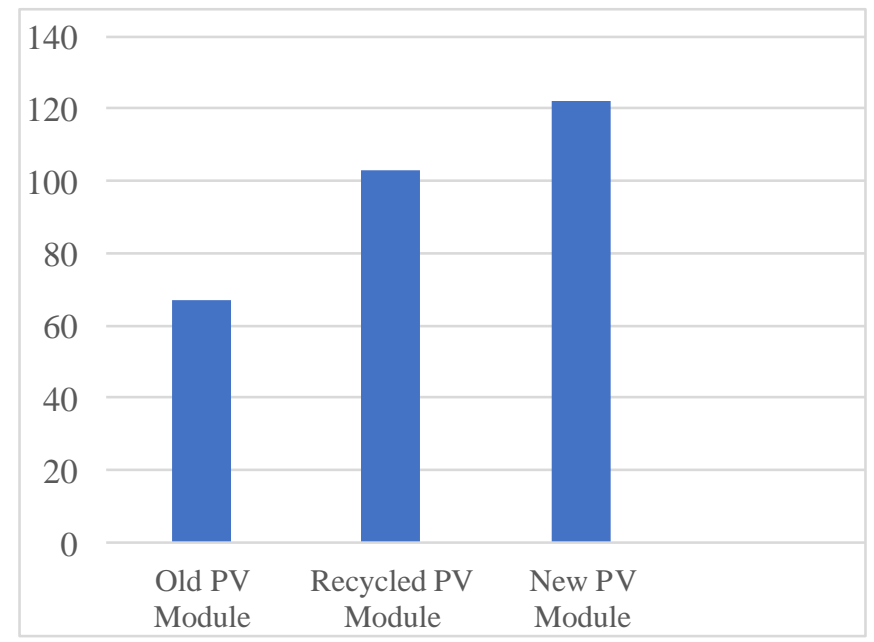

Figure 1(a). Bar graph representation of maximum power of recycled photovoltaic module compared to old and new photovoltaic module [8] 


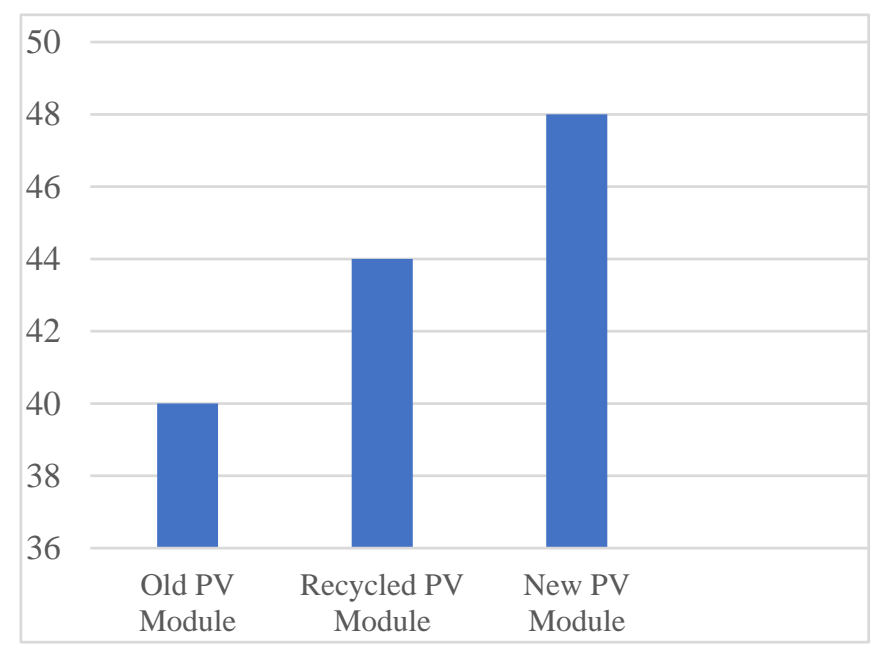

Figure 1(b). Bar graph representation of open circuit voltage of recycled photovoltaic module compared to old and new photovoltaic module [8]

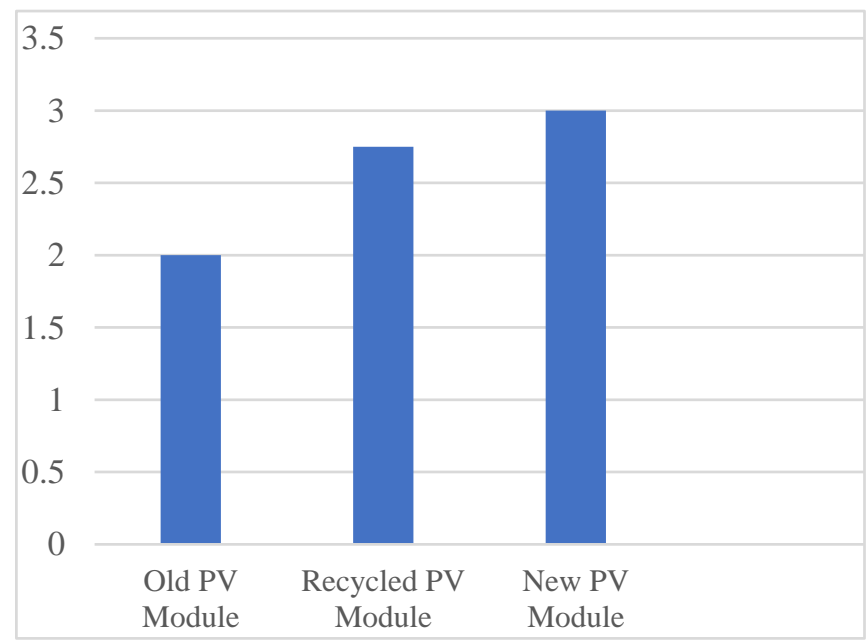

(a) PV module current (A)

Figure 1(c). Bar graph representation of short circuit current of recycled photovoltaic module compared to old and new photovoltaic module [8]

Pavan Gangwar et al [9] conducted a study on the end-of-life management of a solar photovoltaic tree. The schematic pattern of the solar photovoltaic tree developed as the prototype is shown in Fig. 2. End-of-life management of the solar photovoltaic tree was carried out using thermal and chemical treatments and then followed by the dismantling process. According to the study authors, in the first phase the solar photovoltaic tree was dismantled into its individual components. Once dismantling was complete, the photovoltaic modules then underwent thermal and chemical treatment processes which were done separately. However, this study does have certain limitations. The thermal decomposition and dissolution process could lead to cell defects and the release of harmful emissions. There may also be a chance for metal impurities to form on the surface of solar cells.

Marina M. Lunardi et al [10] used Life Cycle Assessment (LCA) to compare different forms of endof-life management of photovoltaic modules, including landfill, incineration and finally reuse and recycling (through mechanical, thermal and chemical methods). The environmental impacts of each method was analysed. The authors concluded that recycling is more beneficial to the environment as compared to the other methods because it enables the glass and silicon to be recycled which can then be reused in the production of new solar modules. The impacts for resource depletion $(\mathrm{ReCiPe})$ were 
also investigated because various forms of transportation have a sizeable impact on the environment. Therefore, fixed or portable small recycling facilities and the use of toxic substances in the chemical methods of recycling should be considered.

G. Nagababu et al [11] studied the potential availability of solar energy in India's Exclusive Economic Zone (EEZ) as a preliminary estimation to develop offshore solar power plants due to low land availability. The authors of the study employed a Geographic Information System (GIS) environment to develop maps with different classes of spatial distribution of the annual mean Global Horizontal Irradiation (GHI) and corresponding solar energy output. Based on the results obtained, the western coast of the Indian EEZ will have greater solar radiation than its eastern counterpart.

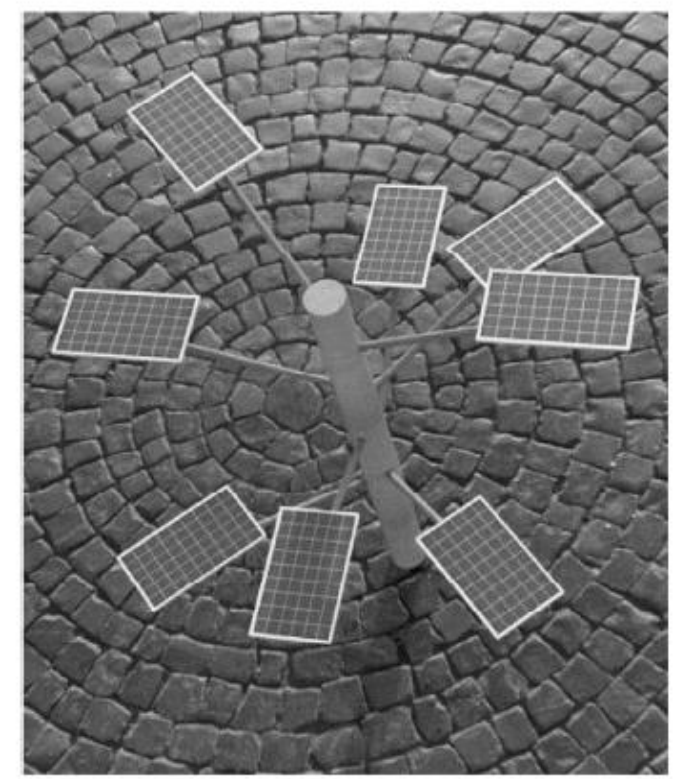

Figure 2. 3/8 phyllotaxy pattern based solar photovoltaic tree (SPVT) [9]

Using the LCA method, B. Mendecka and L. Lombardi [12] assessed the environmental impacts of a hybrid energy system based on the integration of a Waste-to-Energy (WTE) plant with a concentrated solar energy plant. WTE is used to create saturated steam while thermal power is used to overheat the steam. The research aims to reduce global warming and this is achieved by deriving $67 \%-86 \%$ of WTE's operating period and the remaining part from the solar segment. The main contributor to global warming in this case is the combustion of natural gas in the backup boiler. Thus, in order to minimise its global warming indicator, the integrated system was built according to the highest solar multiple values and the highest storage periods, thereby reducing the use of natural gas.

According to previous studies, recycling solar cells is beneficial because it can reduce solar cell waste. However, it cannot control the global rise in temperatures and mitigate carbon emissions. The solar cell industry, which undertakes the recycling process, still contributes to global temperature rise and an increase in carbon emissions as a result of manufacturing activities on their production lines. So, in order to overcome this worldwide issue, this research intends to introduce a self-sustaining solar module by upcycling solar cells from non-biodegradable waste.

Non-biodegradable waste from solar modules present valuable metals such as silver (Ag), gallium $(\mathrm{Ga})$, indium (In), germanium $(\mathrm{Ge})$, cadmium $(\mathrm{Cd})$, and telluride $(\mathrm{Te})$; conventional resources such as aluminium (Al), copper $(\mathrm{Cu})$, and glass, and also highly pure material such as the silicon ( $\mathrm{Si}$ ). Other than that, solar cell waste also contains hazardous and toxic materials such as lead $(\mathrm{Pb})$ and cadmium (Cd). In solar modules, front glass is the most dominant element which contributes to almost $60 \%$ of the total solar module weight, followed by the aluminium which is approximately $17 \%$ of the total mass, where about $14.7 \%$ found in the frame and another $2.01 \%$ in the solar cell. Copper material 
which is used in the solar cell and electrical cable holds nearly $3.89 \%$ of the total solar module [9][13]. Table 1 shows the non-biodegradable materials present in solar module waste and its recovery rate through the upcycling process.

\begin{tabular}{|c|c|}
\hline Types of Materials & Recovery Rates (\%) \\
\hline Aluminium & 100 \\
\hline Glass & 100 \\
\hline Silicon & 95 \\
\hline Silver & 94 \\
\hline Copper & 99 \\
\hline Lead & 93 \\
\hline
\end{tabular}

Degradation rate of solar panel is very important to be understood as it could reduce the performance of solar panel which is based on the measurement of electrical parameters rated by the maximum power, maximum current, maximum voltage, short circuit current and open circuit voltage, fill factor and the experimental I-V and P-V characteristics [14]. The performance of solar module can be referred as the ability of glass cover to allow radiation to penetrate through the collection surface [15]. Degradation rate of solar panel can be affected by two sources, which are environmental source and intrinsic source. Environmental or extrinsic sources may come up from temperature, humidity and oxygen-rich condition while intrinsic sources may come up from the characteristics of solar cells itself such as material used and the interface chemistries under working conditions [16].

\section{SIMULATION, RESULTS AND DISCUSSION}

This section is divided into three main parts, namely simulation, proceeded by results and discussion. The importance of design phase is to model and simulate the solar module before the hardware part is developed.

\subsection{Simulation}

A simulation as shown in Fig. 3 (a) and (b) was developed using the Proteus software. The simulation is comprised of a combination of two and three solar cells. The solar cells are connected in series to boost up the voltage level while the total current flow is constant. 
8OL-1.
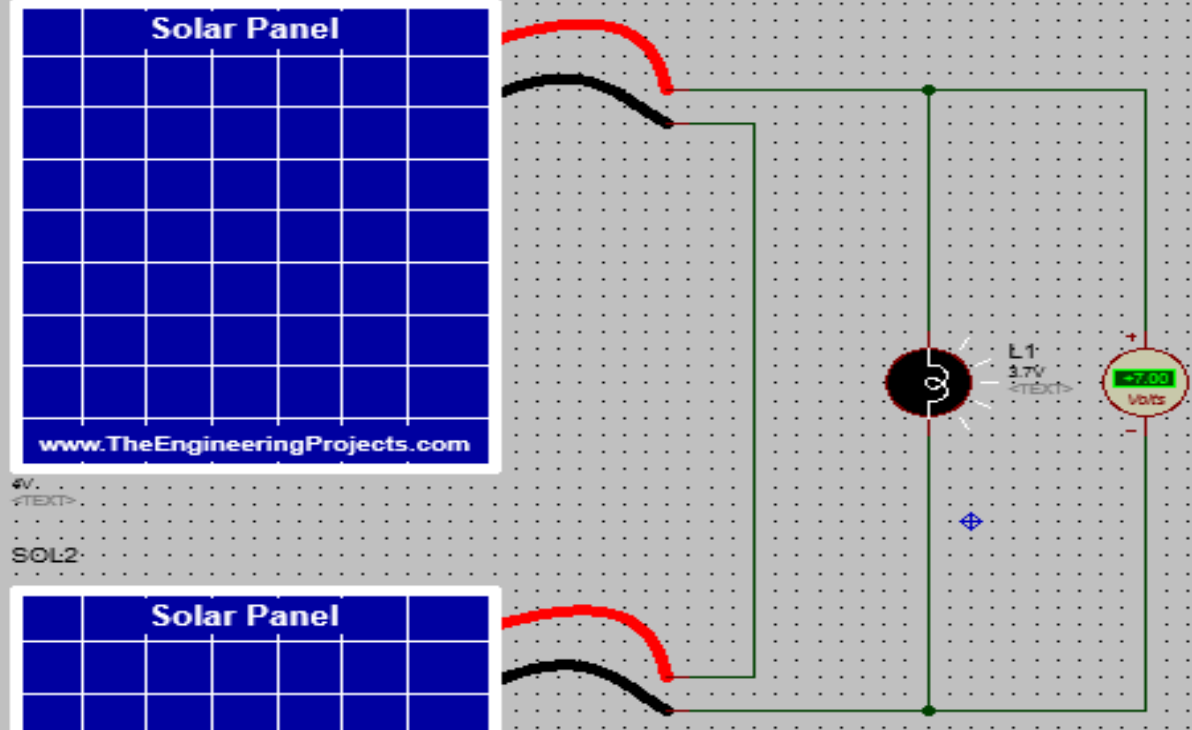

Sல்:2.

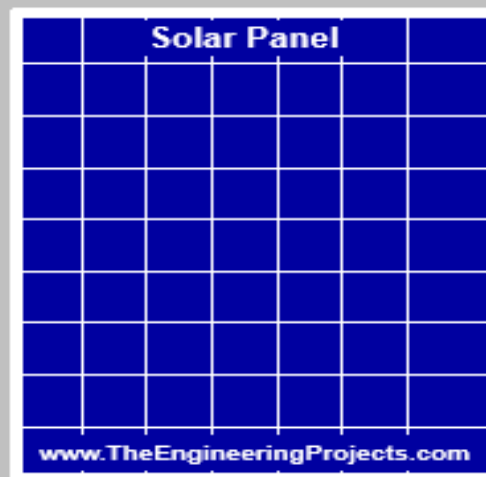

Figure 3(a). Simulation of a combination of $4 \mathrm{~V}$ and $3 \mathrm{~V}$ solar cells

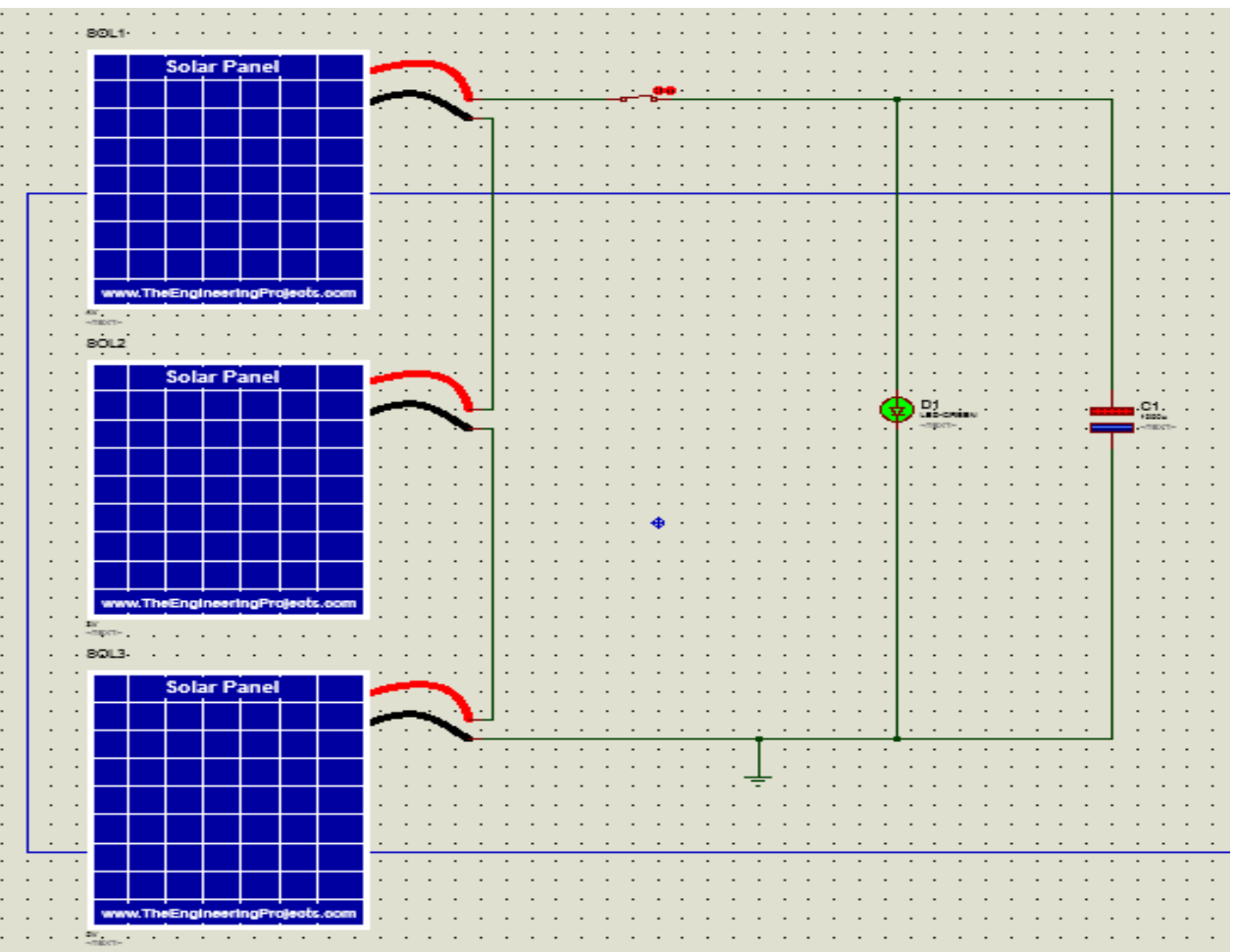

Figure 3(b). Simulation of a combination of $4 \mathrm{~V}, 3 \mathrm{~V}$, and $2 \mathrm{~V}$ solar cells connected in series 
An LED was added to act as a charging indicator. When the switch is turned on, current flows and the LED lights up to indicate that the battery is charging. When the switch is off, there is no current flow in the circuit.

\subsection{Results}

For the experiment, a simple self-sustaining solar system was designed and developed with reused solar cells from electronic devices. Fig. 4 illustrates the method proposed.

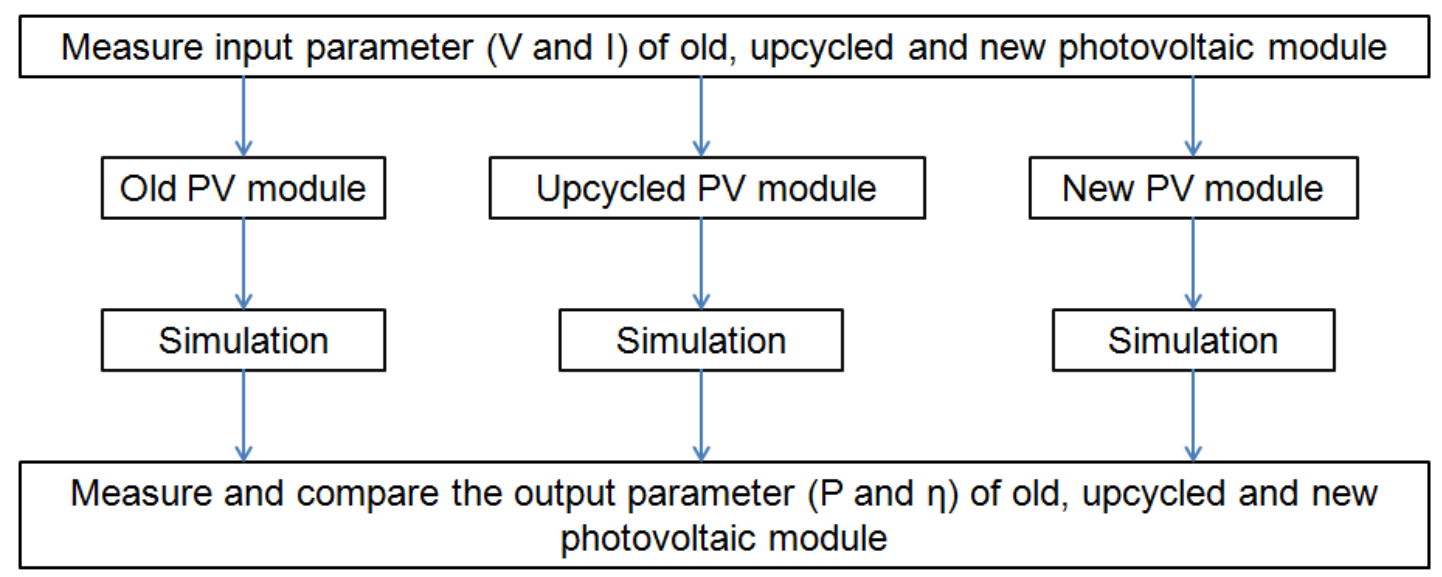

Figure 4. Method used in the experiment

Reused/old solar cells from solar-powered path lights as shown in Figure 5 (a) were used in this experiment. The solar cells used were rated $4 \mathrm{~V}, 3 \mathrm{~V}$ and $2 \mathrm{~V}$, respectively. The solar-powered path light that had been disassembled into its component parts is shown in Figure 5 (b). Figure 6 shows a combination comprising of $4 \mathrm{~V}$ and $3 \mathrm{~V}$ solar cells in an electrical circuit. This simple circuit is used to charge a lithium battery with a voltage of $3.7 \mathrm{~V}$.

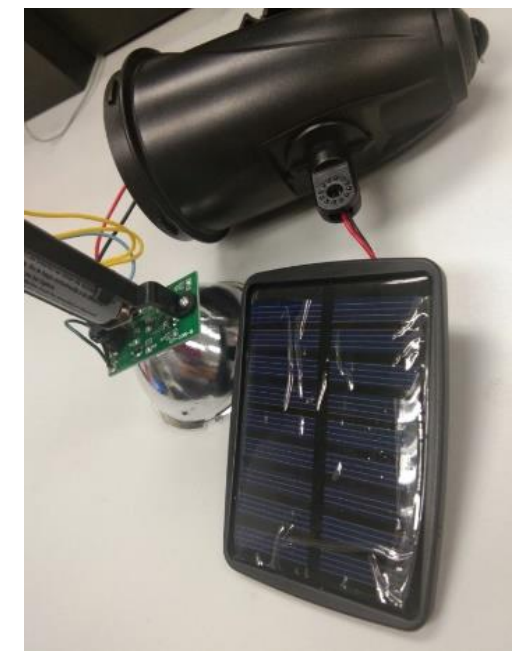

(a)

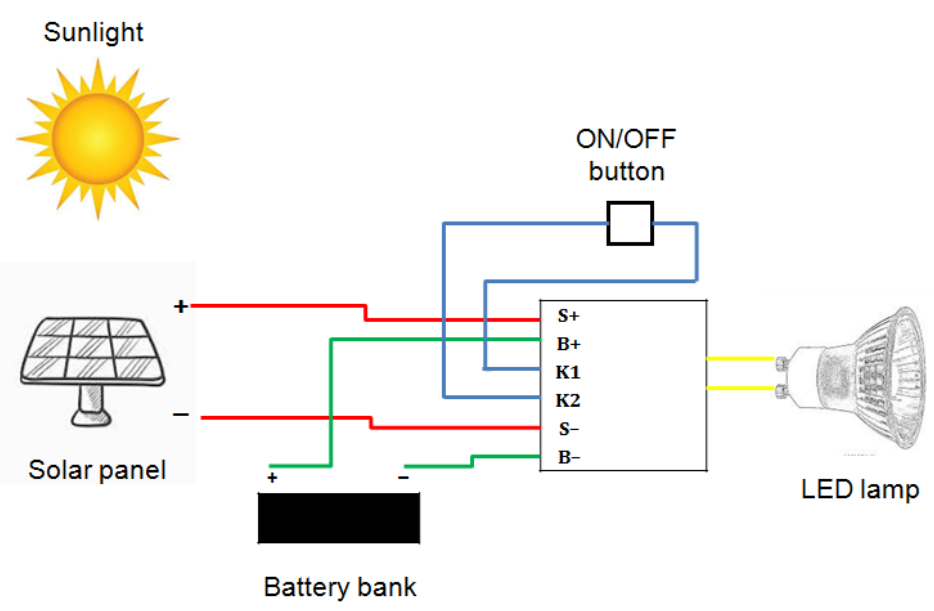

(b)

Figure 5(a). Solar cells from solar-powered path light and (b) an illustration of the solar-powered path light's complete circuit 


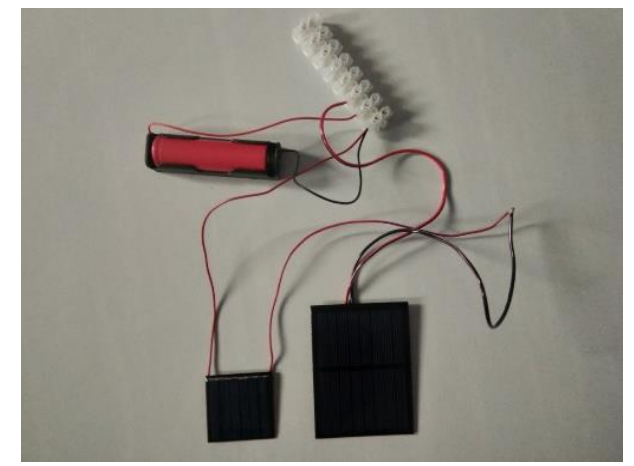

Figure 6. A combination of two solar cells connected in series

The power capacity of the system is calculated as:

$$
P=V I
$$

where $\mathrm{P}$ is the electric power, $\mathrm{V}$ is the voltage differences and $\mathrm{I}$ is the current flow through the system. The efficiency of the system is calculated as follows:

$$
\eta=\frac{P_{\text {out }}}{P_{\text {in }}} \times 100 \%
$$

where " $\eta$ " is the efficiency of the system, Pout is the output power and Pin is the input power. The results obtained were recorded and subsequently compared to new photovoltaic cells.

The solar battery charger as shown in Figure 7 and Figure 8 is composed of three solar panel rated at $4 \mathrm{~V}, 3 \mathrm{~V}$, and $2 \mathrm{~V}$, two pieces of $3.7 \mathrm{~V}$ lithium rechargeable batteries, a motor, and a switch.

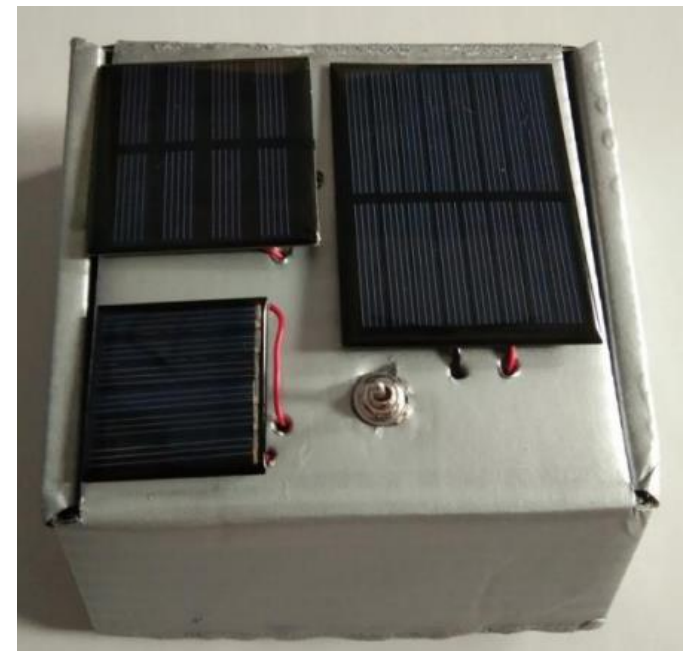

Figure 7. Outside view of self-sustaining solar system 


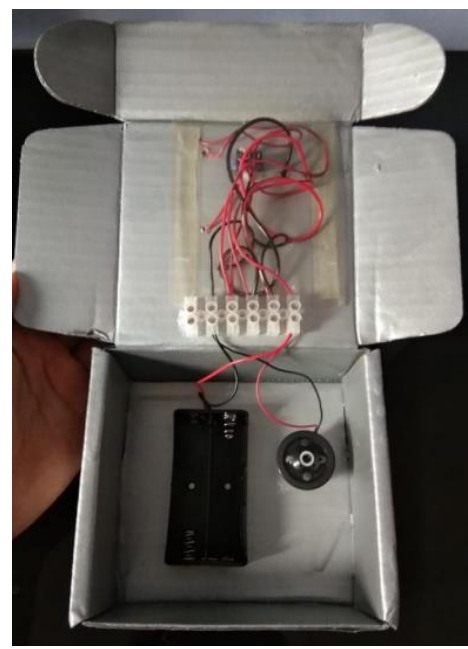

Figure 8. Inside view of self-sustaining solar system

A 5.9V DC motor was added to act as a charging indicator. When the switch is turned on, current flows and the motor rotates to indicate that the battery is charging. When the switch is turned off, motor stops rotating, indicates that batteries are not in charging mode. The time taken for the batteries to fully-charge is controlled manually. If batteries are fully-charged, motor keeps rotating even when the switch is turned off. It takes 2 to 4 hours to fully-charge the batteries.

\subsection{Discussions}

The results tabulated in Table 2 shows that the combination of two new solar panels in series increases the voltage level. In this experiment, the output voltage (V) and output current (I) of the solar modules were recorded. These data were then utilised to measure the maximum output power delivered from the solar cells using Equation (1). The theoretical data was obtained from the solar-powered path light's specifications as provided in its datasheet. As for the experimental data, it was recorded based on two distinct times, specifically day (in the presence of sunlight) and night (in total darkness). The current generated from the solar modules is linearly dependent on the solar radiation. Hence, no currents are produced by the solar modules in a no-light condition.

The reused solar cells were connected in series in order to produce higher output voltages, to support the charging of two batteries, both rated at $3.7 \mathrm{~V}$. The combination of $4 \mathrm{~V}$ and $3 \mathrm{~V}$ solar cells provided $8.04 \mathrm{~V}$ and produced $41 \mathrm{~mW}$ of power. After adding a $2 \mathrm{~V}$ solar cell into that combination, the voltage and power generated increased commensurately to $10.20 \mathrm{~V}$ and $47.9 \mathrm{~mW}$, respectively. Solar panels arranged in series connection sum up the voltages of each individual reused solar cell used, and give the maximum output voltage as shown in the table. The higher total voltage produced by the solar modules promoting a higher output power.

The output current of combination of $4 \mathrm{~V}$ and $3 \mathrm{~V}$ solar cells array give $0.051 \mathrm{~A}$. This value decreases to $0.047 \mathrm{~A}$ after solar cells rated at $2 \mathrm{~V}$ is added to that combination. This shows that the value of total output current is limited to the solar cell with the lowest rated current used in that array; where in this experiment is $3 \mathrm{~V}$ solar cell with current drew $0.049 \mathrm{~A}$. On other hand, solar cells rated at $4 \mathrm{~V}, 0.110 \mathrm{~A}$ and $2 \mathrm{~V}, 0.098 \mathrm{~A}$ only use about half of its maximum current potential, hence reducing the maximum output power delivered of the series connected array even under maximum solar radiation.

From this experiment, upcycled solar modules with high power outputs could be produced by combining reused solar cells in series. However, individual upcycled solar cell should have the same or in average total current rating in order to achieve the highest efficiency from the series connection of solar panel. 
Table 2. The Output Voltage, Current and Power from New Solar Cells

\begin{tabular}{|c|c|c|c|}
\hline Activities & Theoretical data & $\begin{array}{c}\text { Experimental Data } \\
\text { (Day) }\end{array}$ & $\begin{array}{c}\text { Experimental data } \\
\text { (Night) }\end{array}$ \\
\hline 4V solar cell & $\begin{array}{l}\mathrm{V}=4.000 \mathrm{~V} \\
\mathrm{I}=0.150 \mathrm{~V} \\
\mathrm{P}=0.600 \mathrm{~W}\end{array}$ & $\begin{array}{l}\mathrm{V}=4.610 \mathrm{~V} \\
\mathrm{I}=0.110 \mathrm{~A} \\
\mathrm{P}=0.507 \mathrm{~W}\end{array}$ & $\begin{array}{c}\mathrm{V}=2.240 \mathrm{~V} \\
\mathrm{I}=0 \mathrm{~A}\end{array}$ \\
\hline 3V solar cell & $\begin{array}{l}\mathrm{V}=3.000 \mathrm{~V} \\
\mathrm{I}=0.065 \mathrm{~A} \\
\mathrm{P}=0.195 \mathrm{~W}\end{array}$ & $\begin{array}{l}\mathrm{V}=3.500 \mathrm{~V} \\
\mathrm{I}=0.049 \mathrm{~A} \\
\mathrm{P}=0.172 \mathrm{~W}\end{array}$ & $\begin{array}{c}\mathrm{V}=1.780 \mathrm{~V} \\
\mathrm{I}=0 \mathrm{~A}\end{array}$ \\
\hline 2V solar cell & $\begin{array}{l}\mathrm{V}=2.000 \mathrm{~V} \\
\mathrm{I}=0.150 \mathrm{~A} \\
\mathrm{P}=0.300 \mathrm{~W}\end{array}$ & $\begin{array}{l}\mathrm{V}=2.280 \mathrm{~V} \\
\mathrm{I}=0.098 \mathrm{~A} \\
\mathrm{P}=0.223 \mathrm{~W}\end{array}$ & $\begin{array}{c}\mathrm{V}=1.210 \mathrm{~V} \\
\mathrm{I}=0 \mathrm{~A}\end{array}$ \\
\hline $\begin{array}{c}\text { Combination of } 4 \mathrm{~V} \text { and } \\
3 \mathrm{~V} \text { solar cells }\end{array}$ & - & $\begin{array}{l}\mathrm{V}=8.040 \mathrm{~V} \\
\mathrm{I}=0.051 \mathrm{~A} \\
\mathrm{P}=0.410 \mathrm{~W}\end{array}$ & $\begin{array}{c}\mathrm{V}=1.850 \mathrm{~V} \\
\mathrm{I}=0 \mathrm{~A}\end{array}$ \\
\hline $\begin{array}{l}\text { Combination of } 4 \mathrm{~V}, 3 \mathrm{~V} \text {, } \\
\text { and } 2 \mathrm{~V} \text { solar cells }\end{array}$ & - & $\begin{array}{l}\mathrm{V}=10.20 \mathrm{~V} \\
\mathrm{I}=0.047 \mathrm{~A} \\
\mathrm{P}=0.479 \mathrm{~W}\end{array}$ & $\begin{array}{c}\mathrm{V}=4.750 \mathrm{~V} \\
\mathrm{I}=0 \mathrm{~A}\end{array}$ \\
\hline
\end{tabular}

For future works, some recommendations that can improve this research are as follows:

i. This research is only focusing on the upcycled solar cells for developing small portable solar devices. Further studies can be conducted for a large-scale implementation of self-sustaining solar system to supply power especially in rural areas by taking into account the cost of battery bank.

ii. Other than combining the solar panel in series connection, new design of solar modules can be done through the combination of solar panel in parallel connection. With this configuration, the output current of the solar modules can be increased, and voltage value is constant. The effect of rising current in the solar battery charger could be analysed.

iii. To improve the functionality of the solar battery charger, charging controller or charging indicator could be added to prevent batteries from overcharging and thus affect its performance and lifespan.

\section{CONCLUSIONS}

The findings obtained from this study shows that a combination involving the use of reused solar cells from non-biodegradable waste resulted in an increase of the power output performance. This research is generally in accordance and in line with WTE projects for the development of Renewable Energy (RE) in Malaysia which will contribute to a cost reduction in RE management and more importantly mitigate carbon emissions and global warming. It also has the potential to strengthen existing government plans and policies to promote the use of clean and renewable energy sources so as to ultimately achieve the Sustainable Development Goals (SDGs) as set out by the United Nations.

\section{ACKNOWLEDGEMENT}

The authors would like to thank to Universiti Sains Islam Malaysia for their cooperation in this research paper. 


\section{REFERENCES}

[1] I. J. Ahluwalia and U. Patel, "Solid Waste Management in India An Assessment of Resource Recovery and Environmental Impact," Indian Council for Research on International Economic Relations, no. 356, pp. 1-48, 2018.

[2] M. M. Tun, D. Juchelková, H. Raclavská, and V. Sassmanová, "Utilization of Biodegradable Wastes as a Clean Energy Source in the Developing Countries: A Case Study in Myanmar," Energies, vol. 11, no. 11, pp. 1-20, 2018.

[3] R. Deng, N. L. Chang, Z. Ouyang, and C. M. Chong, "A techno-economic review of silicon photovoltaic module recycling," Renewable and Sustainable Energy Reviews, vol. 109, no. 109 , pp. 532-550.

[4] T. Shevchenko, K. Laitala, and Y. Danko, "Understanding Consumer E-Waste Recycling Behavior: Introducing a New Economic Incentive to Increase the Collection Rates," Sustainability, vol. 11, no. 9, 2019.

[5] L. L. Barnes, "Environmental Impact of Solar Panel Manufacturing and End-of-Life Management : Technology and Policy Options," Illinois Sustainable Technology Center, 2017.

[6] H. Ashfaq, I. Hussain, and A. Giri, "Comparative analysis of old, recycled and new PV modules," Journal of King Saud University - Engineering Sciences, vol. 29, no. 1, pp. 22-28, 2017.

[7] A. Abate, "Perovskite Solar Cells Go Lead Free," Joule, vol. 1, no. 4, pp. 659-664, 2017.

[8] J. Manachi, E. Bohulu, K. Harding, M. Low, and D. Ming, "Powering the future: Zinc-air batteries and solar panels," Procedia Manufacturing, vol. 35, pp. 749-754, 2019.

[9] P. Gangwar, N. M. Kumar, A. K. Singh, A. Jayakumar, and M. Mathew, "Solar photovoltaic tree and its end-of-life management using thermal and chemical treatments for material recovery," Case Studies in Thermal Engineering, vol. 14, 2019.

[10] M. M. Lunardi, J. P. Alvarez-Gaitan, J. I. Bilbao, and R. Corkish, "Comparative Life Cycle Assessment of End-of-Life Silicon Solar Photovoltaic Modules," Applied Sciences, vol. 8, no. 8, 2018.

[11] C. Solanki, G. Nagababu, and S. S. Kachhwaha, "Assessment of offshore solar energy along the coast of India," Energy Procedia, vol. 138, pp. 530-535, 2017.

[12] B. Mendecka and L. Lombardi, "Environmental evaluation of Waste to Energy plant coupled with concentrated solar energy," Energy Procedia, vol. 148, pp. 162-169, 2018.

[13] I. D'Adamo, M. Miliacca, and P. Rosa, "Economic Feasibility for Recycling of Waste Crystalline Silicon Photovoltaic Modules," International Journal of Photoenergy, vol. 2017, pp. 1-7, 2017.

[14] H. D. Ndiath, P. W. Tavarez, S. Thiao, A. Mar, A. T. Niang, B. Mbow, and I. Youm, "Degradation Assessment of a Photovoltaic Plant After Several Years of Operation," Science Journal of Energy Engineering, vol. 6, no. 1, p. 1, 2018.

[15] R. Karmouch and H. EL Hor H., "Solar Cells Performance Reduction under the Effect of Dust in Jazan Region," Journal of Sustainable Energy, vol. 08, no. 01, pp. 12-15, 2017.

[16] L. Qiu, L. K. Ono, and Y. Qi, "Advances and challenges to the commercialization of organicinorganic halide perovskite solar cell technology," Materials Today Energy, vol. 7, pp. 169189, 2018. 